\title{
PENERAPAN TEKNOLOGI USAHATANI PADI SAWAH PADA KELOMPOK TANI SOKO MERAS DI KELURAHAN TARATARA SATU KECAMATAN TOMOHON BARAT KOTA TOMOHON
}

\author{
Aurelia Margaretha Kaparang \\ Noortje Marselianie Benu \\ Vicky Richard B. Moniaga
}

Naskah diterima melalui Website Jurnal Ilmiah agrisosioekonomi@ unsrat.ac.id

: Jumat, 20 Desember 2019

Disetujui diterbitkan

Rabu, 08 Januari 2020

\begin{abstract}
This study aims to determine the application of paddy farming technology in the Soko Meras farmer group in Taratara Satu Village, Tomohon Barat District, Tomohon City. This research was conducted in July - September 2019. Types of data used in this study are primary and secondary data. Primary data were collected from interviews conducted with all 13 members of the Soko Meras farmer group using a survey method (census) using a questionnaire. Secondary data is data obtained from the Statistics Office of Tomohon City. The results showed that the Soko Meras farmer group had applied agricultural technology in the paddy field farming. All members of the farmer group have implemented agricultural machinery such as tractors for land management, already applying the jajar legowo method in planting. Using sprayers to control pests and diseases. At the threshing stage of rice that has used threshing machines for harvesting. *eprm*
\end{abstract}

Keywords: application; technology; farming; lowland rice.

\begin{abstract}
ABSTRAK
Penelitian ini bertujuan untuk mengetahui penerapan teknologi usaha tani padi sawah pada kelompok tani Soko Meras di Kelurahan Taratara Satu Kecamatan Tomohon Barat Kota Tomohon. Penelitian ini dilakukan bulan Juli - September 2019. Jenis data yang digunakan dalam penelitian ini adalah data primer dan sekunder. Data primer dikumpulkan dari wawancara yang dilakukan pada seluruh anggota kelompok tani Soko Meras sebanyak 13 anggota dengan menggunakan metode survei (sensus) menggunakan daftar pertanyaan (kuesioner). Data sekunder data yang diperoleh dari kantor Badan Pusat Statistika Kota Tomohon. Hasil penelitian menunjukkan bahwa kelompok tani Soko Meras telah menerapkan teknologi pertanian dalam berusahatani padi sawah. Seluruh anggota kelompok tani sudah menerapkan mesin pertanian seperti traktor untuk pengolahan lahan, sudah menerapkan metode jajar legowo dalam penanaman. Menggunakan alat penyemprot untuk pengendalian hama dan penyakit. Pada tahap perontokan padi yang telah menggunakan mesin perontok untuk panen. ${ }^{*}$ prm*
\end{abstract}

Kata kunci : penerapan; teknologi; usahatani; padi sawah.

\section{PENDAHULUAN}

\section{Latar Belakang}

Zaman yang serba modern ini semuanya tidak terlepas dari penggunaan teknologi. Bahkan dalam pertanian, para petani juga mulai menggunakan teknologi pertanian guna membantu dalam penyelesaian pekerjaan. Kelompok tani ini akan membentuk komunitas petani dalam rangka mempermudah pengadaan sarana produksi pertanian, seperti bibit, pupuk maupun obat-obatan. Hal ini akan lebih efektif 
jika dilakukan oleh kelompok tani daripada secara individu karena biaya pengadaan sarana produksi pertanian dapat ditanggung bersama. Kelompok tani dibentuk oleh dan untuk petani, guna mengatasi masalah bersama dalam usahatani (Sunanto, 2004)

Kelompok tani dianggap sebagai organisasi yang efektif untuk memberdayakan petani, meningkatkan produktivitas, pendapatan, dan kesejahteraan petani dengan bantuan fasilitasi pemerintah melalui program dari berbagai kebijakan pembangunan pertanian, maka perlu dikaji pula perannya dalam mempercepat penerapan teknologi. Kelompok tani berfungsi sebagai unit produksi, yang dilaksanakan oleh masing-masing anggota kelompok tani secara keseluruhan sebagai satu kesatuan usaha yang dapat dikembangkan untuk mencapai skala ekonomi, baik dipandang dari segi kuantitas, kualitas maupun kontinuitas (Syahyuti, 2007).

Keberadaan kelompok tani di Indonesia telah lama ada sebagai lembaga komunikasi antar petani dalam menjalankan aktifitasnya. Kelompok tani merupakan beberapa orang petani yang menghimpun diri dalam suatu kelompok karena memiliki keserasian dalam tujuan, motif, dan minat. Umumnya kelompok tani dibentuk atas dasar kesamaan tujuan, kesamaan kepentingan dan kesamaan kondisi dalam suatu lingkungan petani. Dalam perkembangan selanjutnya, sebagian besar kelompok tani di Indonesia tidak dibentuk oleh dan untuk petani, melainkan lebih banyak merupakan respon dari program-program pemerintah yang mengharuskan petani berkelompok. Dengan dibentuknya kelompok tani mempermudah untuk penyampaian materi penyuluhan berupa pembinaan dalam memberdayakan petani agar memiliki kemandirian dalam penggunaan teknologi pertanian. Kelompok tani yang dinamis ditandai oleh selalu adanya kegiataan ataupun interaksi, baik didalam maupun dengan pihak luar dalam upaya mencapai tujuan kelompok (Syahyuti, 2007).

Adapun untuk mendapatkan hasil yang memuaskan setiap anggota kelompok tani maka teknologi pertanian yang telah disalurkan oleh pemerintah harus digunakan sebaik mungkin. Dalam perkembanganya kelompok tani ini telah banyak melakukan inovasi-inovasi pertanian yang sangat membantu petani dalam melakukan cocok tanam khususnya dalam menggunakan teknologi pertanian, hal itu diwujudkan dengan penggunaan traktor sawah untuk membajak, dulu masyarakat masih memanfaatkan tenaga kerbau/sapi untuk membajak sawah, namun hal itu memakan waktu yang lama.

Kelurahan Taratara Satu Kecamatan Tomohon Barat, padi sawah merupakan komoditas yang banyak dijumpai. Dalam budidayanya mulai dari proses penanaman padi, proses pemupukan, pengendalian gulma, hama dan penyakit hingga panen memerlukan teknologi pertanian yang dapat membantu para kelompok tani. Kelompok tani diharuskan mampu dalam penggunaan setiap teknologi pertanian yang telah disalurkan oleh pemerintah. Disamping itu untuk dapat menggunakan teknologi pertanian yang modern secara efektif, maka kelompok tani perlu mendapatkan bimbingan lewat kegiatan yang menunjang dan meningkatkan kemampuan setiap para anggotanya.

Kelompok tani yang berada di Kelurahan Taratara Satu adalah kelompok tani Soko Meras. Kelompok tani ini sudah lama terbentuk sehingga relasi antar anggotanya sangat erat. Apabila salah satu anggota kelompok akan melakukan aktifitas atau kegiatan budidaya, anggota yang lain akan ikut serta membantu. Anggota kelompok tani dapat dengan mudah menggunakan teknologi pertanian karena mengikuti penyuluhan yang dilakukan oleh para penyuluh dari Dinas Pertanian. Berdasarkan penjelasan tersebut, peneliti merasa tertarik untuk melakukan kajian tentang penerapan teknologi usahatani padi sawah pada kelompok tani soko meras di Kelurahan Taratara Satu.

\section{Rumusan Masalah}

Berdasarkan latar belakang yang telah di kemukakan, maka masalah dari penelitian ini yaitu bagaimana penerapan teknologi usahatani padi sawah di Kelurahan Taratara Satu Kecamatan Tomohon Barat Kota Tomohon?

\section{Tujuan Penelitian}

Tujuan penelitian ini adalah untuk mengetahui penerapan teknologi usaha tani padi sawah pada kelompok tani Soko Meras di Kelurahan Taratara Satu Kecamatan Tomohon Barat Kota Tomohon. 


\section{Manfaat Penelitian}

Penelitian ini diharapkan dapat memberikan informasi dan masukkan pada masyarakat dan pihak-pihak yang membutuhkan khususnya pada anggota kelompok tani di Kelurahan Taratara Satu Kecamatan Tomohon Barat Kota Tomohon.

\section{METODE PENELITIAN}

\section{Waktu dan Lokasi Penelitian}

Penelitian ini berlangsung selama 3 bulan yaitu dari bulan Juli sampai bulan September tahun 2019 mulai persiapan sampai penyusunan laporan penelitian. Penelitian ini di laksanakan di Kelurahan Taratara Satu Kecamatan Tomohon Barat.

\section{Metode Pengambilan Sampel}

Objek dalam penelitian ini adalah seluruh anggota kelompok tani Soko Meras sebanyak 13 anggota dengan menggunakan metode survei (sensus) menggunakan daftar pertanyaan (kuesioner)

\section{Metode Pengumpulan Sampel}

Penelitian ini menggunakan data primer dan sekunder. Data Primer yang diperoleh melalui metode wawancara yang berpedoman pada daftar pertanyaan (quesioner) kepada Kelompok Tani Sako Meras yang ada di kelurahan Taratara. Data sekunder diperoleh dari beberapa instansi yang bersifat melengkapi data primer yang berhubungan dengan penelitian ini.

\section{Konsep dan Pengukuran Variabel}

Variabel yang diukur dalam penelitian ini adalah :

1. Karakteristik responden
a. Umur : tahun
b. Tingkat pendidikan responden : SD, SMP, SMA, PT
c. Posisi dalam kelompok tani : Ketua/Sekertaris/Bendahara/Anggota
d. Jumlah tanggungan dalam keluarga ...orang
e. Pendapatan : Rp/Bln
f. Lama usahatani : ........
g. Luas Lahan : .......

2. Penerapan teknologi usahatani padi sawah

a. Proses penanaman padi

1. Jenis benih yang digunakan

2. Pengolahan lahan
a) Tenaga hewan
b) Mesin
c) Peralatan

3. Penanaman
a) Jajar legowo
b) Tanam Manual

b. Proses pemupukan

1. Jenis pupuk yang digunakan

c. Pengendalian gulma, hama dan penyakit

1. Penggunaan pestisida

2. Penggunaan Mekanik

d. Penggunaan alat dan mesin pertanian
1. Cangkul
2. Parang
3. Hand Tractor
4. Mesin Perontok
5. Sabit bergerigi
6. Alat Penyemprot

e. Panen

1. Pemanenan

2. Perontokan

3. Pengeringan

4. Penyimpanan

\section{Metode Analisis Data}

Metode analisis data yang digunakan dalam penelitian ini adalah metode deskriptif. Data yang diperoleh disajikan dalam bentuk tabel.

\section{HASIL DAN PEMBAHASAN}

\section{Gambaran Umum Lokasi Penelitian}

Tomohon adalah salah satu kota di Provinsi Sulawesi Utara dengan luas yaitu 147,21 $\mathrm{Km}^{2}$ dengan jarak sekitar $23.000 \mathrm{M}$ dari Kota Manado, ibukota provinsi Sulawesi Utara. Penelitian ini dilaksanakan di Kelurahan Taratara Satu merupakan kelurahan yang ada di Kota Tomohon (BPS dalam Angka Tomohon, 2016).

Kelurahan Taratara Satu memiliki jarak 5 $\mathrm{Km}$, jarak dengan ibukota kabupaten/kota $8 \mathrm{Km}$, dan jarak dengan ibukota provinsi $25 \mathrm{Km}$. Kelurahan Taratara Satu berada pada ketinggian $400 \mathrm{Mdpl}$ (meter diatas permukaan laut). Dengan luas wilayah $\pm 625.5 \mathrm{Ha}$ yang terdiri dari 8 Lingkungan. Batas wilayah administratif Kelurahan Taratara Satu sebagai berikut : 
a. Sebelah Utara berbatasan dengan Kelurahan Taratara Dua.

b. Sebelah Timur berbatasan dengan Kelurahan Taratara Dua dan Woloan Tiga.

c. Sebelah Selatan berbatasan dengan Kelurahan Tincep, Pinaras.

d. Sebelah Barat berbatasan dengan Kelurahan Taratara, Ranotongkor.

(Sumber : Kantor Kelurahan Taratara Satu, 2016).

\section{Karakteristik Kelompok Tani}

Kelompok tani Soko Meras merupakan kelompok tani yang menjadi objek Penelitian dan bertempat di kelurahan Taratara Satu Kecamatan Tomohon Barat Kota Tomohon. Kelompok tani Soko Meras berdiri sejak tahun1996. Diberi nama Soko Meras karena merupakan nama tempatnya yang berada di soko meras. Anggota kelompok tani ini berjumlah 13 orang. Jenis tanaman yang diusahakan oleh kelompok tani ini adalah tanaman padi sawah Struktur organisasi terdiri dari ketua, sekretaris, bendahara dan anggota. Kegiatan kelompok tani Soko Meras seperti pertemuan setiap hari Sabtu dengan kegiatan ibadah dan evaluasi kegiatan kelompok tani.

\section{Karakteristik Responden}

\section{Karakteristik Responden Menurut Tingkat Umur}

Tingkat umur responden bervariasi, mulai dari responden yang berumur 30-an tahun Sampai 70 -an tahun. Hal ini dikarenakan tidak ditentukan mengenai tingkat umur dalam penentuan responden. Pengelompokkan umur responden dilakukan dalam upaya mempermudah proses pengolahan data. Kelompok umur dibagi menjadi 4 kelompok umur dengan selang umur sepuluh tahun. Gambaran mengenai kelompok umur responden dapat dilihat pada Tabel 1 .

Tabel 1. Persentase Responden Menurut Umur

\begin{tabular}{cccc}
\hline No. & $\begin{array}{c}\text { Umur } \\
\text { (Tahun) }\end{array}$ & $\begin{array}{c}\text { Jumlah } \\
\text { Responden } \\
\text { (Orang) }\end{array}$ & $\begin{array}{c}\text { Persentase } \\
(\%)\end{array}$ \\
\hline 1. & $30-40$ & 2 & 15,4 \\
2. & $41-50$ & 3 & 23,1 \\
3. & $51-60$ & 5 & 38,4 \\
4. & $>60$ & 3 & 23,1 \\
\hline & Jumlah & $\mathbf{1 3}$ & $\mathbf{1 0 0}$ \\
\hline
\end{tabular}

Sumber : Diolah dari Data Primer 2019
Tabel 1 menunjukkan bahwa usia responden yang berumur 30-40 tahun yaitu berjumlah1 responden dengan persentase $15,4 \%$. Sedangkan responden yang berumur 41-50 dan > 60 memiliki persentase yang sama yaitu $23,1 \%$ dengan jumlah 3 responden dan yang berumur 5160 berjumlah 5 responden dengan persentase 38,4. Responden yang berumur 51-60 merupakan persentase nilai yang terbanyak atau merupakan umur responden terbanyak.

\section{Karakteristik Responden Menurut Tingkat Pendidikan}

Semakin tinggi tingkat pendidikan seseorang semakin banyak pula pengetahuan atau wawasan yang dimiliki, baik itu menciptakan, menerapkaan teknologi baru serta inovasi-inovasi yang baru. Tingkat pendidikan responden dapat dilihat pada Tabel 2.

Tabel 2. Persentase Responden Menurut Pendidikan

\begin{tabular}{clcc}
\hline No. & $\begin{array}{c}\text { Tingkat } \\
\text { Pendidikan }\end{array}$ & $\begin{array}{c}\text { Jumlah } \\
\text { Responden } \\
\text { (Orang) }\end{array}$ & $\begin{array}{c}\text { Persentase } \\
(\boldsymbol{\%})\end{array}$ \\
\hline 1. & SD & 2 & 15,4 \\
2. & SMP & 9 & 69,2 \\
3. & SMA & 2 & 15,4 \\
\hline & Jumlah & $\mathbf{1 3}$ & $\mathbf{1 0 0}$ \\
\hline
\end{tabular}

Sumber : Diolah dari Data Primer 2019

Tabel 2 menunjukkan bahwa persentase yang sama terlihat pada responden dengan tingkat pendidikan SD dan SMA yang memiliki persentase $15,5 \%$ dengan responden masingmasing berjumlah 2 orang. Persentase terbesar terlihat pada responden dengan tingkat pendidikan SMP yang memiliki persentase $69,2 \%$. Hal ini membuktikan bahwa tingkat pendidikan responden cukup baik walaupun masih ada responden dengan tingkat pendidikannya hanya sampai SD.

\section{Karakteristik Responden Menurut Jumlah Tanggungan \\ Jumlah tanggungan keluarga dalam} penelitian ini adalah banyaknya anggota keluarga yang terdiri dari : istri dan anak, serta orang lain yang tinggal dalam satu rumah dan makan bersama yang menjadi tanggungan kepala keluarga. Banyaknya anggota dalam keluarga dapat dilihat pada Tabel 3. 
Tabel 3. Persentase Responden Menurut Tanggungan Kepala Keluarga

\begin{tabular}{cccc}
\hline No. & $\begin{array}{c}\text { Jumlah } \\
\text { Tanggungan }\end{array}$ & $\begin{array}{c}\text { Jumlah } \\
\text { Responden } \\
\text { (Orang) }\end{array}$ & $\begin{array}{c}\text { Persentase } \\
(\boldsymbol{\%})\end{array}$ \\
\hline 1. & $<3$ & 5 & 38,5 \\
2. & $3-5$ & 7 & 53,8 \\
3. & $>5$ & 1 & 7,7 \\
\hline & Jumlah & $\mathbf{1 3}$ & $\mathbf{1 0 0}$ \\
\hline
\end{tabular}

Sumber : Diolah dari Data Primer 2019

Tabel 3 menunjukkan bahwa jumlah tanggungan keluarga yang lebih kecil dari 3 orang anggota keluarga sebanyak 5 responden dengan persentase $38,5 \%$, sedangkan jumlah tanggungan keluarga yang 3 sampai 5 orang anggota keluarga sebanyak 7 orang dengan persentase 53,8\% dan jumlah tanggungan lebih besar dari 5 orang anggota keluarga sebanyak 1 responden dengan persentase $7,7 \%$. Banyaknya anggota keluarga menggambarkan besarnya beban ekonomi yang ditanggung kepala keluarga, karena hidup dari satu sumber penghasilan.

4. Karakteristik Responden Menurut Status Kepemilikan Lahan

Salah satu yang mempengaruhi tingkat pendapatan petani adalah status kepemilikan lahan. Status kepemilikan lahan yang dimiliki oleh responden dapat dilihat pada Tabel 4.

Tabel 4. Persentase Responden Menurut Status Kepemilikan Lahan

\begin{tabular}{cccc}
\hline No. & $\begin{array}{c}\text { Status } \\
\text { Kepemilikan } \\
\text { Lahan }\end{array}$ & $\begin{array}{c}\text { Jumlah } \\
\text { Responden } \\
\text { (Orang) }\end{array}$ & $\begin{array}{c}\text { Persentase } \\
(\mathbf{\%})\end{array}$ \\
\hline 1. & Hak Milik & 9 & 69,2 \\
2. & Bagi hasil & 4 & 30,8 \\
3. & Sewa & 0 & 0 \\
\hline & Jumlah & $\mathbf{1 3}$ & $\mathbf{1 0 0}$ \\
\hline
\end{tabular}

Sumber : Diolah dari Data Primer 2019

Tabel 4 menunjukkan bahwa status kepemilikan lahan yang digarap responden, sebanyak 9 responden memiliki lahan sendiri dengan persentase $69,23 \%$ yang merupakan persentase terbesar, dan 4 responden termasuk dalam bagi hasil dengan persentase $30,77 \%$. Dari data pada Tabel 4 terlihat bahwa rata-rata anggota kelompok tani Soko Meras banyak yang mempunyai lahan milik sendiri.
5. Karakteristik Responden Menurut Lama Usahatani

Lamanya berusahatani setiap anggota kelompok tani sangat diperlukan karena melihat seberapa lama pengalaman mereka dalam berusahatani, ditunjukkan pada Tabel 5 .

Tabel 5. Persentase Responden Menurut Lama Usahatani

\begin{tabular}{cccc}
\hline No. & $\begin{array}{c}\text { Lama } \\
\text { Usahatani } \\
\text { (Tahun) }\end{array}$ & $\begin{array}{c}\text { Jumlah } \\
\text { Responden } \\
\text { (Orang) }\end{array}$ & $\begin{array}{c}\text { Persentase } \\
(\boldsymbol{\%})\end{array}$ \\
\hline 1. & $<20$ & 2 & 15,4 \\
2. & $20-30$ & 5 & 38,5 \\
3. & $>30$ & 6 & 46,1 \\
\hline & Jumlah & $\mathbf{1 3}$ & $\mathbf{1 0 0}$ \\
\hline
\end{tabular}

Sumber : Diolah dari Data Primer 2019

Tabel 5 menunjukkan bahwa lamanya berusahatani pada responden kurang dari 20 tahun ada 2 orang dengan persentase $15,4 \%$ sedangkan lamanya berusahatani pada responden 20 sampai 30 tahun ada 5 orang dengan persentase $38,5 \%$. Persentase terbanyak yaitu $46,1 \%$ berada pada responden lebih besar dari 30 yaitu sebanyak 6 orang. Berdasarkan penelitian yang ditunjukkan pada Tabel 5 anggota kelompok tani soko meras rata-rata memiliki pengalaman yang baik dalam berusahatani yang dilihat dari tahun setiap anggota memulai berusahatani.

\section{Usahatani Padi Sawah}

\section{Luas Lahan}

Tanah atau lahan merupakan salah satu faktor yang penting dalam bidang usaha pertanian. Semakin luas lahan yang digarap maka semakin tinggi tingkat pendapatan petani. Sebaliknya, semakin sempit luas lahan yang digarap maka semakin rendah tingkat pendapatan petani. Ini menunjukkan bahwa luas lahan menentukan tingkat pendapatan petani. Luas lahan dapat dilihat pada Tabel 6 .

Tabel 6. Persentase Responden Menurut Luas Lahan

\begin{tabular}{cccc}
\hline No. & $\begin{array}{c}\text { Luas Lahan } \\
(\mathbf{H a})\end{array}$ & $\begin{array}{c}\text { Jumlah } \\
\text { Responden } \\
\text { (Orang) }\end{array}$ & $\begin{array}{c}\text { Persentase } \\
(\boldsymbol{\%})\end{array}$ \\
\hline 1. & $<0,5$ & 0 & 0 \\
2. & $0,5-1$ & 11 & 84,6 \\
3. & $>1$ & 2 & 15,4 \\
\hline & Jumlah & $\mathbf{1 3}$ & $\mathbf{1 0 0}$ \\
\hline
\end{tabular}

Sumber : Diolah dari Data Primer 2019 
Tabel 6 menunjukkan bahwa luas lahan yang digarap responden terbanyak yaitu 0,5 sampai $1 \mathrm{Ha}$ oleh 11 responden dengan persentase $84,6 \%$ dan responden yang menggarap lebih besar dari $1 \mathrm{Ha}$ sebanyak 2 responden dengan persentase $15,4 \%$.

\section{Pendapatan}

Pendapatan petani sangat berpengaruh pada harga jual padi. Berdasarkan hasil penelitian, harga jual beras di Keluarahan Taratara Satu berkisar antara Rp.8.000 sampai dengan Rp.10.000. Jika dirupiahkan rata-rata pendapatan petani padi sawah dalam sekali panen dapat dilihat pada Tabel 7.

Tabel 7. Pendapatan Responden Dalam Satu Kali Panen ( 3 Bulan)

\begin{tabular}{cccc}
\hline No. & $\begin{array}{c}\text { Pendapatan } \\
\text { (Rp/3 bulan) }\end{array}$ & $\begin{array}{c}\text { Jumlah } \\
\text { Responden } \\
\text { (Orang) }\end{array}$ & $\begin{array}{c}\text { Persentase } \\
(\boldsymbol{\%})\end{array}$ \\
\hline 1 & $1.000 .000-3.000 .000$ & 4 & 30,8 \\
2 & $>4.000 .000$ & 9 & 69,2 \\
\hline & Jumlah & $\mathbf{1 3}$ & $\mathbf{1 0 0}$ \\
\hline
\end{tabular}

Sumber : Diolah dari Data Primer 2019

Tabel 7 menunjukkan bahwa terdapat 9 responden yang mempunyai pendapatan lebih dari 4.000.000 per satu kali panen dengan persentase $69,2 \%$, dan merupakan persentase terbesar. Sedangkan pendapatan pada 1.000 .000 sampai 3.000.000 terdapat 4 responden dengan persentase $30,8 \%$.

\section{Penerapan Teknologi}

\section{Benih}

Benih yang unggul sangat diperlukan untuk mencapai hasil yang memuaskan sehingga dapat meningkatkan pendapatan petani. Untuk melihat jenis-jenis benih yang digunakan kelompok tani soko meras dapat dilihat pada Tabel 8 .

Tabel 8. Persentase Responden Menurut Jenis Benih Padi Yang Digunakan

\begin{tabular}{clcc}
\hline No. & Jenis Benih & $\begin{array}{c}\text { Jumlah } \\
\text { Responden } \\
\text { (Orang) }\end{array}$ & $\begin{array}{c}\text { Persentase } \\
\mathbf{( \% )}\end{array}$ \\
\hline 1 & Cigendit & 2 & 15,4 \\
2 & Mekongga & 3 & 23,1 \\
3 & Ciherang & 5 & 38,4 \\
4 & IR64 & 3 & 23,1 \\
\hline & Jumlah & $\mathbf{1 3}$ & $\mathbf{1 0 0}$ \\
\hline
\end{tabular}

Sumber : Diolah dari Data Primer 2019
Tabel 8 menunjukkan responden yang menggunakan benih cigendit sebanyak 2 responden dengan persentase 15,4\%. Responden yang menggunakan benih mekongga dan IR64 masing-masing sebanyak 3 responden dengan persentase 23,1 . Sedangkan benih yang paling banyak digunakan yaitu ciherang sebanyak 5 responden dengan persentase 38,4. Ciherang merupakan benih yang banyak ditanam oleh anggota kelompok tani soko meras karena memiliki banyak kelebihan. Kelebihan jenis benih ciherang adalah menghasilkan beras yang pulen dan enak. Mampu beradaptasi di segala tempat kondisi alam sehingga cocok ditanam pada musim hujan dan kemarau.

\section{Persemaian Benih}

Persemaian benih dilakukan agar nantinya benih dapat berproduksi dengan optimal serta menghasilkan padi yang bermutu.

Hasil penelitian menunjukkan bahwa seluruh anggota kelompok tani soko meras merendam benih menggunakan wadah yang telah dipersiapkan untuk benih bertumbuh. Setelah itu disebarkan dilahan yang sudah disiapkan dan kemudian ditutup dengan pelepah daun kelapa untuk mempercepat pertumbuhan dan melindungi bibit.

\section{Pengolahan Lahan}

Pengolahan lahan merupakan salah satu komponen yang penting dalam proses usahatani padi sawah. Pengolahan lahan meliputi pekerjaan membajak, mengcangkul dan meratakan lahan. Pengolahan lahan berfungsi untuk menyiapkan terlebih dahulu lahan yang akan digunakan untuk melakukan kegiatan penanaman padi. Dalam pengolahan lahan dapat dibantu dengan tenaga hewan atau mesin/peralatan.

Hasil penelitian menunjukkan bahwa seluruh anggota kelompok tani soko meras menggunakan mesin dalam pengolahan lahan dibandingkan menggunakan tenaga hewan atau peralatan. Penggunaan mesin sangat membantu dan mempermudah para anggota kelompok tani dalam pengolahan lahan. Selain dapat menghemat waktu dapat juga menghemat tenaga dalam pengembangan usahatani padi dibandingkan dengan tenaga hewan maupun tenaga manusia. 


\section{Penanaman}

Penanaman padi sawah umumnya ditanam dengan jarak teratur antara padi diusahakan jangan terlalu dekat atau terlalu rapat.

Hasil penelitian menunjukkan bahwa seluruh anggota kelompok tani soko meras menerapkan sistem tanam jajar legowo dibandingkan dengan cara manual yaitu dengan hanya memperkirakan kesejajaran padi yang sudah ditanam terlebih dahulu dan jarak antar padi. Sistem tanam jajar legowo memudahkan dalam penyebaran pupuk serta ada ruang cukup untuk pengaturan air sehingga sangat baik bagi perkembangan dan pertumbuhan tanaman. Jajar legowo juga dianjurkan oleh dinas pertanian untuk diterapkan oleh setiap anggota kelompok tani soko meras.

\section{Pemupukan}

Pemupukan merupakan salah satu komponen penting dalam melakukan proses usahatani padi sawah. Tanaman padi memerlukan unsur hara untuk pertumbuhan dan perkembangannya. Untuk mengetahui persentase jenis pupuk yang digunakan oleh anggota kelompok tani soko meras dapat dilihat pada Tabel 9.

Tabel 9. Persentase Responden Menurut Penerapan Teknologi Dalam Tahap Pemupukan Padi Sawah Kelompok Tani Soko Meras

\begin{tabular}{cccc}
\hline No. & Jenis Pupuk & $\begin{array}{c}\text { Jumlah } \\
\text { Responden } \\
\text { (Orang) }\end{array}$ & $\begin{array}{c}\text { Persentase } \\
(\boldsymbol{\%})\end{array}$ \\
\hline 1 & Urea dan TSP & 4 & 30,8 \\
2 & Urea dan Gandasil & 9 & 69,2 \\
\hline & Jumlah & $\mathbf{1 3}$ & $\mathbf{1 0 0}$ \\
\hline
\end{tabular}

Sumber : Diolah dari Data Primer 2019

Tabel 9 menunjukkan bahwa responden yang menggunakan pupuk jenis Urea dan TSP Triple Super Phosphate sebanyak 4 orang dengan persentase 30,8\% sedangkan responden yang menggunakan jenis pupuk Urea dan Gandasil 9 orang dengan persentase 69,2\%. Dan responden yang menggunakan pupuk Gandasil sebanyak 2 responden dengan persentase 15,4\%. Kebanyakan anggota kelompok tani soko meras menggunakan jenis pupuk Urea untuk fase vegetatif dan menggunakan jenis pupuk Gandasil untuk fase generative.
6. Pengendalian gulma, hama dan penyakit

Dalam melakukan budidaya padi sawah pengendalian gulma, hama dan penyakit merupakan hal yang penting dan harus diperhatikan karena akan sangat berpengaruh pada hasil yang akan didapat. Untuk mengetahui jenis pestisida yang digunakan anggota kelompok tani soko meras dapat dilihat pada Tabel 10.

\begin{tabular}{clcc}
\multicolumn{3}{c}{$\begin{array}{c}\text { Tabel 10. Persentase Responden Menurut Penerapan Teknologi } \\
\text { Dalam } \\
\text { Penyakit Padi Sawah Kelompok Tani Soko Meras }\end{array}$} \\
\hline No. & Jenis Pestisida & $\begin{array}{c}\text { Jumlah } \\
\text { Pesponden } \\
\text { (Orang) }\end{array}$ & $\begin{array}{c}\text { Persentase } \\
(\boldsymbol{\%})\end{array}$ \\
& & 2 & 15,4 \\
\hline 1. & Curacron & 7 & 53,8 \\
2. & Trisula & 4 & 30,8 \\
3. & Desis & $\mathbf{1 3}$ & $\mathbf{1 0 0}$ \\
\hline \multicolumn{5}{c}{ Jumlah } &
\end{tabular}

Tabel 10 menunjukkan bahwa responden yang menggunakan jenis pestisida Curacron sebanyak 2 responden dengan persentase 15,4\% sedangkan yang menggunakan jenis pestisida Trisula merupakan jenis yang banyak dipakai yaitu sebanyak 7 responden dengan persentase $53,8 \%$. Dan responden yang menggunakan jenis pestisida Desis sebanyak 4 responden dengan persentase $30,8 \%$.

\section{Penggunaan Alat dan Mesin Pertanian}

Penggunaan alat-alat pertanian yang sifatnya masih sederhana sampai alat dan mesin pertanian yang rumit dari penerapan teknologi tujuannya adalah untuk meningkatkan produktivitas kerja. Untuk melihat penggunaan alat dan mesin pertanian dapat dilihat pada Tabel 11 .

Tabel 11. Persentase Responden Menurut Penggunaan Alat dan Mesin Pertanian Padi Sawah Kelompok Tani Soko Meras

\begin{tabular}{clcc}
\hline No. & $\begin{array}{c}\text { Peralatan/Mesin } \\
\text { Pertanian }\end{array}$ & $\begin{array}{c}\text { Responden } \\
\text { (Orang) }\end{array}$ & $\begin{array}{c}\text { Persentase } \\
(\boldsymbol{\%})\end{array}$ \\
\hline 1 & Mesin Perontok & 13 & 100 \\
2 & Alat Penyemprot & 13 & 100 \\
3 & Traktor & 13 & 100 \\
\hline
\end{tabular}

Sumber : Diolah dari Data Primer 2019

Tabel 11 menunjukkan bahwa rata-rata responden telah menggunakan teknologi pertanian berupa mesin perontok, alat penyemprot, traktor, dibandingkan dengan alat tradisional seperti cangkul, sabit bergerigi dan parang, guna membantu para anggota kelompok tani soko meras dalam proses usahatani padi sawah. 


\section{Panen dan Pasca Panen}

Panen merupakan proses akhir dalam usahatani padi sawah. Sementara pasca panen meliputi pemanenan, perontokan, pengeringan dan penyimpanan.

Tahap pemanenan, seluruh anggota kelompok tani soko meras masih melakukan cara manual yaitu dengan alat tradisional yang mereka buat sendiri. Alat tersebut berupa pisau yang diikatkan dengan kayu. Hal ini karena belum adanya alat/mesin pemanen padi.

Tahap perontokan, seluruh anggota kelompok tani soko meras menggunakan mesin perontok dalam memisahkan biji padi dengan batang padi. Tidak lagi secara manual seperti batang padi dibanting pada papan perontok untuk memisahkan biji dengan batang padi.

Tahap pengeringan, seluruh anggota kelompok tani soko meras melakukan pengeringan padi sawah dengan cara menjemur padi dengan bantuan sinar matahari.

Tahap penyimpanan, seluruh anggota kelompok tani soko meras setelah padi dikeringkan diisi ke dalam karung yang telah disiapkan kemudian disimpan ke dalam ruangan atau gudang.

\section{KESIMPULAN DAN SARAN}

\section{Kesimpulan}

Penerapan teknologi pertanian usahatani padi sawah oleh Kelompok Tani Soko Meras tergolong baik. Hal ini dapat dilihat dari beberapa tahap budidaya padi sawah yang menerapkan teknologi pertanian seperti dalam tahap :

1. Pengolahan lahan. Seluruh anggota kelompok tani sudah menerapkan mesin pertanian seperti traktor.

2. Penanaman. Seluruh anggota kelompok tani soko meras sudah menerapkan metode jajar legowo yang merupakan anjuran dari pemerintah dalam proses penanaman.

3. Panen dan Pasca panen. Seluruh anggota kelompok tani soko meras sudah menerapkan teknologi pertanian seperti pada tahap perontokan padi yang telah menggunakan mesin perontok.
4. Penggunaan alat dan mesin pertanian seluruh anggota kelompok tani soko meras sudah mampu menerapkan alat/mesin pertanian modern seperti mesin perontok, alat penyemprot, traktor dibandingkan dengan alat tradisional seperti cangkul, sabit bergerigi, parang.

\section{Saran}

1. Peran pemerintah dalam pemberian akses untuk kelompok tani soko meras sangatlah penting dan dibutuhkan setiap anggota kelompok tani dalam berusahatani. Seperti pemberian dana untuk membeli pupuk serta pestisida dan penambahan teknologi untuk digunakan.

2. Para anggota kelompok tani soko meras kiranya tetap mempertahankan penerapan teknologi yang sudah dilakukan serta lebih rajin dalam mengikuti penyuluhan agar semakin baik dalam penerapan teknologi yang ada sehingga dapat lebih baik lagi.

\section{DAFTAR PUSTAKA}

Badan Pusat Statistik Kota Tomohon. 2016. Tomohon dalam angka. Tomohon.

Sunanto, H. 2004. Budidaya, Pengolahan Hasil, dan Aspek Ekonominya. Kanisius Yogyakarta.

Syahyuti. 2007. Kebijakan Pengembangan Gabungan Kelompok Tani (Gapoktan) sebagai Kelembagaan Ekonomi di Perdesaan. Jurnal Analisis Pertanian Vol.5 no. 1. Maret. 